University for Business and Technology in Kosovo

UBT Knowledge Center

Oct 28th, 9:00 AM - Oct 30th, 5:00 PM

\title{
Joint Venture as a market entry mode into the foreign market. Case study: Kosova
}

\author{
Nehat Ramadani \\ University for Business and Technology, nehat.ramadani@ubt-uni.net
}

Follow this and additional works at: https://knowledgecenter.ubt-uni.net/conference

Part of the Business Commons

\section{Recommended Citation}

Ramadani, Nehat, "Joint Venture as a market entry mode into the foreign market. Case study: Kosova" (2016). UBT International Conference. 21.

https://knowledgecenter.ubt-uni.net/conference/2016/all-events/21

This Event is brought to you for free and open access by the Publication and Journals at UBT Knowledge Center. It has been accepted for inclusion in UBT International Conference by an authorized administrator of UBT Knowledge Center. For more information, please contact knowledge.center@ubt-uni.net. 
Book of Proceedings

International Conference on Management, Business and Economics

\title{
"Joint Venture as a market entry mode into the foreign market. Case study: Kosova"
}

\author{
Nehat Ramadani \\ UBT - Higher Education Institution, Lagjja Kalabria, 10000 p.n., \\ Prishtine, Kosovo \\ nehat.ramadani@ubt-uni.net
}

\begin{abstract}
The economic, political, and social changes that had happened over the last decade have radically changed the landscape of global businesses. The entry mode strategies of multinationals into foreign markets can be analyzed considering two perspectives: ownership and establishment mode. The process of decision making on the mode of entry is a complex issue in international business because of the many factors involved, and also the impact that such a decision could imply to a firm's performance in the external market. This paper focuses on environmental factors such as political and economic issues with the aspect of entrance of foreign banks into Kosova's market. Despite the existence of several studies on the mode of entry into the Balkan countries, little is known about entry modes adopted by the foreign companies when entering Kosova's market. Thus, the present study aims to investigate the Kosova's market within focusing on particularly join venture entrance mode from a banking perspective. The research is based on a case study with a qualitative approach. This paper concludes that the joint venture offer benefits to both partners as well as other stakeholders - providing customers with more and a higher quality variety of banking services.
\end{abstract}

Keywords: International Entry Mode, market, Joint Venture Mode, Banking Sector, Politic dimension.

\section{Introduction}

The globalization of markets has certainly accelerated through almost universal acceptance of the democratic free enterprise model and new communication technologies, including cell phones and the Internet. The economic, political, and social changes that had happened over the last decade have radically changed the landscape of global business. As John Graham, the authors of the book International Marketing (2011) says, we can explain the current interest in international marketing by changing competitive structures, coupled with shifts in demand characteristics in markets throughout the world. Within the increasing globalization of markets, companies know that they are unavoidably enmeshed with foreign customers, competitors, and suppliers, even within their own borders (Ceteora \&Graham J, 2011).

Nine years after declaring independence, Kosovo has made important but incomplete progress on creating the business and legislative environment required to reach its full economic potential. An ongoing dialogue process between Kosovo and EU, is still unclear whether Kosovars will be able to benefit from visa-free travel in Schengen area. A long ongoing dialog with Serbia has resulted in 
"Joint Venture as a market entry mode into the foreign market. Case study: Kosova"

numerous agreements that aim to make the trade, commerce, and travel between the two countries simpler; however, there are still major disagreements left to resolve.

Strategies of entry modes directly impact on other strategic decisions and strongly influence the organization performance. The entry mode strategies of multinationals into foreign markets can be analyzed considering two perspectives: ownership and establishment mode. Modes of entry that involve ownership are divided between wholly owned subsidiaries (WOS) and joint ventures (JV), while the entry modes by establishment mode can be divided between acquisition and greenfield (Fonfara, 2014). According to the Foreign Investment Law, foreign investors may wholly own businesses in all sectors of the economy, with the exception of the manufacture or distribution of military products, where equity is limited to 49 percent. Foreign investors in all other areas are subject to the same licensing requirements as local investors. Foreign investors may be required to file a statement with local authorities identifying principal stakeholders and types of investment. No other filing requirements in excess of those required for similar domestic businesses are required for foreign investors (DBK, 2012).

\section{METHODOLOGY}

Through a single case study, in order to get in depth information about the Kosov's market, this paper utilized a qualitative approach. The data collection instrument used were few interviews as well as available secondary data. Paper work is focused on TEB Bank as a case of joint venture entry mode into Kosova's market. In the next section the literature is reviewed about join venture mode into foreign markets and its determinants. The next part of this paper is focused on Kosova's market and its environmental factors by focusing on economy, financial and banking sector, business environment and politic dimension. There are described also the potential barriers on banking sector in Kosova. In the fifth section are discussed the results of the study. In the last section, are presented the main conclusions of the study. There were three main methods used for the study, a literature review, an internet research of the reports and the case study interview. The literature review was conducted to review the market entry modes of the foreign companies into foreign markets and its determination. An internet research had helped to define the banking sector in Kosova and the business environment and its factors.

\section{THEORETICAL BASIS}

This section presents the market entry mode through Joint Venture and the factors determining the international entry mode choice. Joint ventures are domestic or international enterprises involving two or more companies joining temporarily to undertake a particular project. They have grown in popularity in recent years-joint ventures between U.S. and foreign firms, for example, have increased at an average of 27 percent since 1985. Certainly, not all of them will be successful; estimates of the failure rate of joint ventures reaches as high as 70 percent. Nonetheless, companies persist in initiating them for a variety of reasons. Joint ventures are very helpful to some companies in gaining access into the foreign markets such as Henkel Teroson Automotive, Sony-Ericson, Microsoft and GE Joint Venture, Caradigm or Siemens AG and Nokia Corp Joint Venture. Any party may really be interested in the primary project, but they participate simply to gain access to the new market. Such projects basically represent a direct investment, which is sometimes limited by laws in the country in which the operation 
Book of Proceedings

International Conference on Management, Business and Economics

takes place. One of the aims of a partner in a joint venture is to have a majority interest in it, that way, it maintains control over a project. This explains why some countries such as Russia or China do not permit foreign companies to hold majority interests in their domestic business ventures. More to the point, companies seeking to cut the costs of doing business see joint ventures as a way to save money. In effect, they are sharing the risks should a particular project fail. As it's explainning Ms Duliniec, International marketing (2011) as an example, if two oil companies wish to produce a new drilling platform to search for the oil in swamps or some ocean areas, and neither one can finance the project on its own, they might join forces. In this case they are sharing the costs of the projects and reducing their individual risk should they find no oil. That is a decided advantage to many business people (Duliniec, 2011).

Businesses shouldn't engage into joint ventures without proper planning as well as strategy. They cannot let it be, since the ultimate goal of joint ventures is the same as it is for any type of business operation: to make a good profit for the owners as well as for the shareholders. A successful company in any type of business is often recruited heavily for participation in joint ventures. Thus, they can pick and choose in which partnerships they would like to engage, if any. They follow certain ground rules, which have been developed over they years as joint ventures have grown in popularity(Walas, 2006). The example of the bad strategy of the join venture is Tata Motors Ltd and Italy's Fiat Spa. Fiat joined hands with Tata Motors with the objective of using the latter's expansive sales, service and distribution network to gain access to one of the world's fastest growing car markets. It became evident in the first few years of the joint venture that the model was not working.

Among the benefits which are from joint ventures is that partners save money and reduce their risks through capital and resource sharing. Joint ventures gives the smaller companies the chance to work with larger ones to develop, manufacture as well as market new products. They also give companies of all sizes the opportunity to increase sales, gain access to wider markets, and enhance technological capabilities through research and development underwritten by more than one party (Duliniec 2011).

\section{CASE STUDY: TEB Bank Kosova}

\subsection{TEB Profile}

TEB is an abbreviation from Türk Ekonomi Bankası (Turkish Economy Bank) which was founded in 1927 by private investors as a regional bank under the name of Kocaeli Bankası T.A.Ş. in İzmit. In 1981 the bank was purchased by the Çolakoğlu Group, which changed its name to Türk Ekonomi Bankası A.Ş. in 1982. In March 2005, TEB signed a joint venture agreement with the French BNP Paribas SA, which is one of the largest financial services groups in the world. TEB has been aggressively expanding its retail network in Turkey ever since and had 541 branches as of 2013. TEB has also two other subsidiaries outside Turkey: TEB NV (The Economy Bank) in the Netherlands, and TEB Sh.A. in Kosovo and on the second one the research will focuses on (TEB Bank, 2015).TEB Mali Yatırımlar A.Ş., one of the shareholders with $84,25 \%$ of shares at TEB, which went public in 2000, executed a partnership agreement with BNP Paribas in 2005, which is the six largest bank in the world and is the largest of Euro zone with ongoing operations in 87 countries around the globe. The partnership enabled TEB, one of the respectable and strong brands engaged in the Turkish finance industry, and BNP Paribas, an international brand, to combine the forces and experiences. With this partnership agreement BNP Paribas had shares in TEB Investment, TEB Leasing, TEB Factoring, TEB Insurance, TEB Portfolio Management and TEB NV, a bank of the Netherlands, displaying activities 
"Joint Venture as a market entry mode into the foreign market. Case study: Kosova"

in Amsterdam. BNP Paribas is the first bank of the Euro zone as far as profits and total market capitalisation are concerned. With a prominent and international network of banking, BNP Paribas plays a key role in Corporate and Investment Banking, International Retail Banking and Asset Management. 80 out of the largest 100 group around the globe are customers of BNP Paribas. The target of TEB and BNP Paribas collaboration is to pave the way for a much stronger Turkish bank, as well as to convey and make available international fund of knowledge, services and products of BNP Paribas to a wider range of customer group, and to achieve an international initiative for TEB as a brand. As a significant indication of strong collaboration with BNP Paribas, and of TEB's opening up to the world; TEB has now become involved in the Trade Centres network of BNP Paribas that are established in 48 countries and nearly in 80 locations. Trade Centres that are open in Istanbul, Izmir and Adana throughout Turkey give support for foreign trade consultancy and banking, and offer an international opening for customers. Furthermore, this partnership has allowed TEB to set Turkish Desks in the countries where Turkish entrepreneurs are intensely operating and BNP Paribas has a strong hand.

\subsection{Joint venture as the way of entry TEB Sh. A Bank into Kosovo market}

During the time when TEB Bank decided to enter into Kosovo market, there were no more than two powerfull banks in Kosovo which were dominating this sector. Government wanted to change this situation and to promote opportunities to other banks, in order increase the competition in banking sector. In 2008 TEB decided to enter into Kosovo market, and it was very easy to achieve it. The process of improving banking sector was provided by the USA so the procedures were very clear and the system as strict so there was no risk to enter the market. The political situation didn't influent on the banking sector and the shareholders of the bank had to be sure about that since they decided after analyzing the market to entry there.

Since than this bank has been providing innovative and practical financial products and services. During those nine years TEB had established a trustful reputation, leadership and innovation. Today it is one of the country's leading banks. Both banks decided to entered into Kosovo market within joint venture since both banks equipped with a global banking experience, which enabled them to develop and introduce financial solutions that serve to the best interest of clients based on responsible banking in Kosovo. They goal was to offer a wide range of corporate, commercial, trade finance, SME and individual banking products and services. Is it is shows, they had launched some of the most advanced products in the Kosovo market, including secure e-banking, advanced and fastest payment systems, possibilities for innovative loans and deposits products. As we can find the information on the brochures and internet website of the bank, customers of the TEB Bank are served through an effective branch network, including dedicated business-client centers, and thought a good quality of the delivery channels, including retails and corporate e-banking, call centers ATM's and close to 3,000 POSs. The share capital of the Bank is $€ 24,000,000$ issued shares each with a par value of $€ 10$. Number of shares relates to ordinary shares with no rights, preferences or restrictions attached to them and it is the ownership structure as of June 24, 2013.

\subsection{Environmental factors and entry modes}

Kosovo has the youngest population in Europe and these individuals come into the labor market each year finding limited employment options. An important component of Kosovar life and the labor market is migration. Traditionally, migration has been very high, which in turn has alleviated some of 


\section{Book of Proceedings}

International Conference on Management, Business and Economics

the labor market pressures. Another positive influence from migration is the fact that returning migrants bring to the local market their experience and skills gained abroad. Both these factors coupled with the low wage levels, make local labor an important incentive for investment in Kosovo. By entering the Kosovo market, both banks had to be awarded of a many environmental factors involved, and also the impact that such a decision could imply to a firm's performance in the Kosovo market starting from general information about the country, economy condition of the country and more specific, relating to the sector in which they wanted to act so financial sector of Kosovo as well as banking sector. It is also extremely important question of the political situation of the country, especially in the country, which is still undergoing transformation and reconstruction after the war. In order to analyze these issues, we will bring each of these aspects in the context of the current situation of the country.

\section{○ Economy of Kosovo}

The economy of the country characterize a high reliance on the import of goods which negatively affects the growth rate and the current account balance. Compared to other countries in Southeastern Europe, Kosovo experienced the highest growth rate, noting a real GDP growth of 5 percent in 2011 followed by Macedonia with a growth rate of 3.2 percent. Such growth is mostly attributed to increase of consumption and level of investments. Kosovo's GDP per capita incurred a slight increase by reaching EUR 2,700 in 2011. However, it still continues to be low compared to other countries in the region such as Albania, Bosnia and Herzegovina and Serbia which exceed the amount of EUR 4,000. The inflation rate of 7.3 percent in 2011 more than doubled compared to the prior year. Inflationary pressures were more persistent in the first half of 2011, especially with respect to prices of food products and oil. The main driver of such pressures continues to be prices of imported products which are reflective of prices in the global economy. The current account deficit further deepened in 2011 by reaching around EUR 672 million representing an annual growth of 21 percent. The ratio of deficit to GDP during 2009-11 stands at an average 13 percent of GDP. The main driver for the level of deficit continues to be the trade deficit (KPMG, 2013).

Kosovo is the youngest country in Europe located in the central part of the Balkans. The geographical position of the country enables to serve as a connecting bridge with all other countries of Eastern Europe. Kosovo creates a good conditions for foreign investment. Kosovo currently is a part of free trade within the Central European Free Trade Agreement CEFTA which is enabling its producers to access the regional market of 25 million customers without any customs duty. What is important Kosovo has free unlimited access to the entire European Union market, market with over 500 million customers? In addition, similar agreements exist with the U.S., Japan and Norway. What is important from the TEB Bank point, Kosovo have signed a free trade agreement with Turkey. Kosovo also offers an efficient tax system, citing IMF officials, as the best system in the world after New Zealand. Besides the efficient tax system, Kosovo offers the lowest taxes in Europe, offering foreign investors only $10 \%$ for corporate profits, $5 \%$ compulsory pension contribution and $0 \%$ tax on dividends. Any non-resident person who is subject to taxation in accordance with the tax legislation of the Republic of Kosovo must appoint a fiscal representative prior to starting any economic activity in the Republic of Kosovo. The fiscal representative must register with the Tax Administration of Kosovo within five days of being named. All major sectors of the Kosovo economy are open to foreign investment. In 2011, the Government took substantive steps to further open Kosovo to foreign investment through the passage of the Public Private Partnership (PPP) Law, no. 04 L-045 of 2011. The new PPP Law has been harmonized with the European Council regulations and the EU Acquis Communitaire. The law creates separate definitions for Concession and PPP, meaning that FDI transactions can be structured more flexibly. A provision for unsolicited proposals has been removed, ensuring that all procurements are 
"Joint Venture as a market entry mode into the foreign market. Case study: Kosova"

the result of a competitive bidding process, while prior limits on the length of investment projects have been removed.

\section{- Banking sector in Kosovo}

Financial Sector General characteristics GDP of Kosovo increased by 5 percent in 2011 reaching EUR 4.7 billion. The value of the total financial sector assets at the end of 2011 reached EUR 3.5 billion, which represents an annual increase of 9.3 percent. This indicates a lower growth increase than in 2010 , during which the financial sector assets had an annual growth of 15.1 percent. Commercial banking sector assets comprised around 76.3 percent of the total financial sector assets, while pension funds made up 17.0 percent, microfinance institutions 3.7 percent, followed by insurance companies with 3.0 percent and financial auxiliaries with 0.02 percent.

There are nine banks operating in Kosovo: Bank for Business, Banka Kombetare Tregtare - Kosovo Branch, Economic Bank, Komercijalna Banka ad Beograd - Mitrovica Branch, NLB Prishtina, Procredit Bank, Raiffeisen Bank, Turkiye Is Bankasi and TEB. Foreign banks dominate the market both in terms of the number of banks and their share of the total banking sector assets. Foreign banks in 2011 represented six out of eight commercial banks operating in Kosovo, while they accounted for 89 percent (90.2 percent in 2010) of the total banking sector assets. The three largest banks, Procredit Bank, Raiffeisen Bank and NLB Prishtina, manage 73 percent of the banking sector assets. During 2011, the network of commercial banks continued to expand reaching 311 branches and sub-branches (eight more than in 2010), while the number of staff employed by these banks reached 3,728 compared to 3,610 in 2010. The banking sector is expanding its network also in terms of the number of automated teller machines (ATMs) reaching 460 in 2011 (415 in 2010), and the number of points of sale (POS) that reached 7,534 in 2011 (6,194 in 2010). The number of accounts using e-banking has continued to increase from the previous years, reaching 68,992 in 2011 (55,292 in 2010). This expansion of the banking network through additional banking units and additional services such as ATMs, POS and ebanking has improved the accessibility of clients to banking services. In 2011, the contribution of the banking system accounted for 57.2 percent of the total GDP, which represents a decrease of 1 percent compared to 2010. Assets of the banking sector reached EUR 2.66 billion in 2011, which represents an increase of 8.4 percent compared to 2010 (increase of 9.3 percent in 2010). The value of loans issued from banks in 2011 reached EUR 1.7 billion, which is an increase of 16.4 percent compared to 2010 which itself increased by 13.2 percent compared to 2009. In volume, loans make up 63.6 percent of the total banking system assets (59.4 percent in 2010). The return on average assets (ROAA) remained at the same level as the previous year at 1.5 percent, whereas the return on average equity (ROAE) reached 15.3 percent in 2011, compared to 14.8 percent in 2010 (KPMG, 2013).

In Kosovo commercial banks started opening in the year 2000, after the 1999 conflict and they do their activities under the Kosovo law for banking system and the Central Bank of Kosovo who works as a regulatory instrument (CRIRK, 2015). Nowdays Kosovo's private banking sector remains wellcapitalized and profitable. Difficult economic conditions generally, the lack of strong rule of law and contract enforcement processes, and a risk-averse posture have caused banks to be conservative in lending. This overall cautiousness in the banking sector is evident in its excess reserves, which are above the minimum level required by the Central Bank of Kosovo. Most deposits are demand deposits and total assets of the three largest banks, which are international banks, amount to $71.8 \%$ of the entire banking sector in Kosovo. As of June 2012, Kosovo's banks increased loans at an annual rate of 6\%; however, this was half the rate of the year before. Approximately $76 \%$ of all lending activity is to businesses. Despite positive trends, relatively little lending is directed to long-term investment activities. High interest rates (averaging approximately 14\%) and collateral requirements act as 


\section{Book of Proceedings}

International Conference on Management, Business and Economics

disincentives to borrowers. The slow-down in lending is most notable in the northern part of Kosovo where a weak and ineffectual municipal court system and tension arising from protests and blockades following the government's July 2011 action to take control of its northern border gates have also slowed commercial lending.

\section{- Political dimension}

Before deciding to enter within joint venture bank in Kosovo market, both banks have had to answer the question whether the political situation of the country is stable enough to be able to enter the market, which in their opinion was. An equally important question was whether this young state which is Kosovo has enough legislation regulated by the Bank to be found in the realities of this country. The banking sector in Kosovo was built from scratch in the aftermath of the armed conflict. The main priority in the process was ensuring the stability of the sector, therefore for a new bank to enter in to the Kosovo market significant reserves had to be held by the banks. The country had passed probusiness legislation that specifically seeks to attract foreign investment. Under domestic legislation, foreign firms operating in Kosovo are granted the same privileges as local businesses, except that foreign investors cannot hold more than $49 \%$ ownership in a business producing or selling militaryrelated products (Reg. No. 2001/3, Section 6).

Banking sector is very clear and stable in Kosovo and the barriers are invisible, especially because the country is supervised by the Western countries which makes the procedure in this sector clear. Kosovo is a country oriented into the West that desires to be part the European Union. Current legislation and regulations are written with EU standards in mind.

However economist specialists in Kosovo says that the perceptions of official corruption, the growing state bureaucracy, weak property rights protections, and the lack of universal recognition of Kosovo's 2008 independence at times prove to be obstacles to attracting higher levels of foreign investment as the. These obstacles exist notwithstanding the government's stated pro business posture, the country's strategic location, rich natural resources, low wages, and the entrepreneurial nature of its citizens. In the summer of 2011, a trade dispute with neighboring Serbia, one of Kosovo's trading partners, led to a blockade of cross-border trade between both countries for around two months. Isolated incidents of interethnic as well as sporadic political protests, have occurred since then, but none of these events adversely affected Kosovo's political stability or overall economic situation. The Kosovo Police, Kosovo Security Force, the European Union's Rule-of-Law Mission in Kosovo, and the NATO Kosovo Security Force (KFOR) have responded to and investigated these events, according to their legal mandate. Kosovo's judiciary is augmented by EULEX, which has a Monitoring, Mentoring, and Advising (MMA) role in rule of law matters (Riinvest, 2015).

The World Bank's "Doing Business" Report for 2013 ranks Kosovo 98 out of 185 economies, an improvement of 19 places in one year. Corruption, real and perceived, remains one of the most significant problems in attracting foreign investment in Kosovo. Transparency International's 2012 "Corruption Perceptions Index" ranked Kosovo 105 out of 176 countries and territories surveyed, similar to the prior year's results.

\section{CONCLUSIONS}

Joint ventures can offer a lot of benefits to the potential partner firms through access to new resources including markets, distribution networks, capacity, staff, purchasing, technology, intellectual property, 
"Joint Venture as a market entry mode into the foreign market. Case study: Kosova"

and finance. Often, one firm supplies a key resource such as technology, while the other firms might provide distribution or other assets. There are, however, a number of risks related to joint ventures that can result in loss of control, lower profits, conflict with partners, and transferability of key assets. The case study on TEB Bank illustrates that joint venture offer benefits to both partners as well as other stakeholders - providing customers with more and a higher quality variety of banking services. Today it is one of the country's leading banks what's shows that it was a good position to enter into Kosovo market. Banking sector in Kosovo is clear due the fact that legislation and regulations are written with EU standards in mind. Even if there is many of the potential barriers such as corruption or political violence in Kosovo, they do not influence that much on the banking sector.

There are, however, many risks to be considered for the future for the companies who would like to enter into Kosovo market. Especially taking into account the internal situation of a developing country like Kosovo. The country continues to struggles with problems of imperfect legal situation. There is still a lot of legal gaps that prevent the operation of businesses in such conditions. Focusing on the political situation, as it shown us last year and the beginning of 2016 years the country continues to struggles with internal dilemma. The numerous protests the society caused by bad situation in the country, widespread poverty, unemployment and corruption choking the country affected by the negative sentiment in society. However as the case study of the TEB Bank shown, that is not indicate on the banking sector of the country. Investors are leaving due to the lack of political stability and lack of a suitable business climate. It is normal that investors doesn't want to hold their capital in countries where is a political crises. The political crisis is having an impact in the economy of the country. The teargas let off in the parliament of Kosovo in a very frequent action and it is a very bad signal that can be sent to international partners and potential investors.

International organizations should continue effort to help Kosovo to gain the economic, political and institutional stability in the country. All parliamentary parties must bear in mind the economic consequences that the can cause and that a solution must be found in order to enable institutional stability, which is so important in attracting foreign investments.

\section{REFERENCES}

3. Cateora, P, Gilly, M \& Graham, J (2011), International marketing, Sydney: McGraw Hill,

4. Duliniec, E (2011), Marketing miedzynarodowy.Warszawa: PWE

5. Fonfara, K (2014), Marketing miedzynarodowy - wspolczesne trendy I praktyka, Warsaw: PWN

6. Walas, J (2006), Sposoby wejścia przedsiębiorstw na rynki zagraniczne. Poznan: AEK

7. Center for Research. (2015) Interest Rates in Kosovo's Banking System. Avaliable at: www.cn4hs.org/wp-content/uploads/2015/09/CRDP-Chronicle-Interest-Rates-in-KosovoAugust-31-2015.pdf.

ห. Embassy of Switzerland in Kosovo. (2015) Economic Report Kosovo.

4. Available at: www.s-ge.com/sites/default/files/WB_1510_E_Wirtschaftsbericht-Kosovo.pdf.

10. Government of U.S. (2013) Investment climate statement.

11. www.photos.state.gov/libraries/kosovo/312585/pdf/kosovo_2013_investment_climate_statemen t.pdf.

12. Kosovo Investment and Enterprise Support Agency. (2012) Invest in Kosovo.

13. Available at: www.invest-ks.org/en/welcome-note.

14. KPMG. (2013) Investment in Kosovo. 
Book of Proceedings

International Conference on Management, Business and Economics

15. Available at:

www.kpmg.com/AL/en/IssuesAndInsights/ArticlesPublications/Brochures/Documents/2013Investment-in-Kosovo-website.pdf.

16. National Center for Professional Certification. (2002) Factors Affecting Organizational Climate and Retention. Available at: www.cwla.org./programmes/triechmann/2002fbwfiles.

17. Riinvest Institute (2015) Banking Sector: Facilitator or Barrier Report.

18. Avilable at: www.riinvestinstitute.org/publikimet/pdf/53.pdf

14. TEB BANK. Profile and history information. Available at: www.teb.com.tr/about-teb/history/.

20. US Commercial Service. (2012) Doing Business in Kosovo: 2012 Country Commercial Guide for U.S. Companies. Available at:

www.photos.state.gov/libraries/kosovo/312585/files/2012_Pristina\%20CCG_final.pdf. 